\title{
Taxonomic descriptions of three marine colepid ciliates, Nolandia sinica spec. nov., Apocoleps caoi spec. nov. and Tiarina fusa (Claparède \& Lachmann, 1858) Bergh, 1881 (Ciliophora, Prorodontida)
}

\author{
Xiangrui Chen, ${ }^{1,2}$ Shan Gao, ${ }^{1}$ Weiwei Liu, ${ }^{3}$ Weibo Song, ${ }^{1}$ \\ Khaled A. S. Al-Rasheid ${ }^{4}$ and Alan Warren ${ }^{5}$ \\ ${ }^{1}$ Laboratory of Protozoology, Institute of Evolution and Marine Biodiversity, \\ Ocean University of China, Qingdao 266003, PR China \\ ${ }^{2}$ College of Life Science and Biotechnology, Ningbo University, Ningbo 315211, PR China \\ ${ }^{3}$ Laboratory of Protozoology, South China Normal University, Guangzhou 510631, PR China \\ ${ }^{4}$ Zoology Department, King Saud University, Riyadh 11451, Saudi Arabia \\ ${ }^{5}$ Department of Zoology, Natural History Museum, Cromwell Road, London SW7 5BD, UK
}

Correspondence

Weibo Song

wsong@ouc.edu.cn

\begin{abstract}
The morphology of three marine colepid ciliates, Nolandia sinica spec. nov., Apocoleps caoi spec. nov. and Tiarina fusa (Claparède \& Lachmann, 1858) Bergh, 1881, isolated from Chinese coastal waters, was investigated. N. sinica spec. nov. may be separated from its congeners by the structure of its armour plates, each of which may have up to five reniform windows. A. caoi spec. nov. is characterized by its large body with broad anterior end and by having 10-12 long, sharp posterior spines. New data and an improved diagnosis are supplied for Tiarina fusa (Claparède \& Lachmann, 1858) Bergh, 1881, which has a spindle-shaped body, about 16 ciliary rows and a single adoral organelle. Sequence similarities with other available colepid species were determined.
\end{abstract}

\section{INTRODUCTION}

Colepid ciliates have been studied for more than two centuries since Coleps hirtus (O. F. Müller, 1786) Nitzsch, 1827 was first reported (Müller, 1786). To date, over 40 nominal species have been recorded from a range of habitats worldwide. The most conspicuous apomorphy of the colepids is their armoured pellicle comprising longitudinal rows of calcium carbonate plates with small lateral teeth. Individual taxa may be characterized by a variety of morphological features including the number of armour tiers, the structure of the plates, the presence or absence of spines, and the number of adoral organelles. The majority of colepids have been isolated from freshwater (Dragesco \& Dragesco-Kernéis, 1991; Foissner et al., 1999, 2008; Huttenlauch, 1987; Huttenlauch \& Bardele, 1987; Kahl, 1930, 1933; Noland, 1925, 1937; Obolkina, 1995). By contrast, marine habitats are poorly studied and it is likely that many marine colepids await discovery (Chen et al., 2009, 2010).

The present paper provides morphological descriptions of two novel species, namely Nolandia sinica spec. nov. and Apocoleps caoi spec. nov., from coastal waters of northern
China and new data for a well-known species, Tiarina fusa (Claparède \& Lachmann, 1858) Bergh, 1881, a population of which was isolated from coastal waters of the South China Sea. Molecular information about the two novel species and the Chinese population of Tiarina fusa, including gene sequence data and phylogenetic analyses, have been described by Yi et al. (2010), although the novel species were neither named nor described in this article. In the present paper we compare sequence similarities in order to determine interand intra-generic relationships among the colepids.

\section{METHODS}

Nolandia sinica spec. nov. was collected in May 2007 and Apocoleps caoi spec. nov. in June 2007, from the intertidal regions of sandy beaches near Jiaozhou Bay, Qingdao ( $36^{\circ} 06^{\prime} \mathrm{N} 120^{\circ} 29^{\prime} \mathrm{E}$ ), China. The upper $15 \mathrm{~cm}$ layer of sand was collected together with seawater from the site. Raw cultures were maintained for one or two weeks at room temperature (Wang et al., 2008a, b). Tiarina fusa (Claparède \& Lachmann, 1858) Bergh, 1881 was collected in October 2007 using $20 \mu \mathrm{m}$ plankton nets from coastal waters of Daya Bay, near Shenzhen $\left(22^{\circ} 36^{\prime} 3^{\prime \prime} \mathrm{N} 114^{\circ} 32^{\prime} 46^{\prime \prime} \mathrm{E}\right)$, China. 
Ciliates were observed in vivo using differential interference contrast microscopy (Nikon D80). The infraciliature was revealed by the silver carbonate and protargol impregnation methods (Ma et al., 2003; Song \& Wilbert, 1995). Drawings of stained specimens were made with the help of a camera lucida. Measurements were performed under $\times 100-1250$ magnification. Systematics and terminology are mainly according to Corliss (1979), Foissner et al. (2008) and Chen et al. (2010).

The small subunit (SSU) rRNA gene sequences of N. sinica spec. nov., A. caoi spec. nov. and Tiarina fusa were submitted to the GenBank database by Yi et al. (2010) with the accession numbers FJ858215, HM747137 and FJ858217, respectively. Other sequences used in the present study for comparative purposes were obtained from the GenBank database as follows: Nolandia nolandi (AM292313), Apocoleps magnus (FJ858213), Coleps hirtus hirtus (AM292311), Coleps spetai (AM292312) and Levicoleps biwae (AB354737).

\section{RESULTS}

\section{Nolandia Small \& Lynn, 1985}

\section{Nolandia sinica spec. nov. (Figs 1 and 2; Tables 1-3)}

Diagnosis. Size about $55-65 \times 30-40 \mu \mathrm{m}$ in vivo, body cylindrical in shape; mean 15 transverse and 16 longitudinal ciliary rows; anterior and posterior main plates with five and four reniform windows, respectively; dominant ridge distinct from the left plate margin; one terminal contractile vacuole; marine habitat.

Type locality. Sandy beach near Jiaozhou Bay, Qingdao, China $\left(36^{\circ} 06^{\prime} \mathrm{N} 120^{\circ} 29^{\prime} \mathrm{E}\right)$.

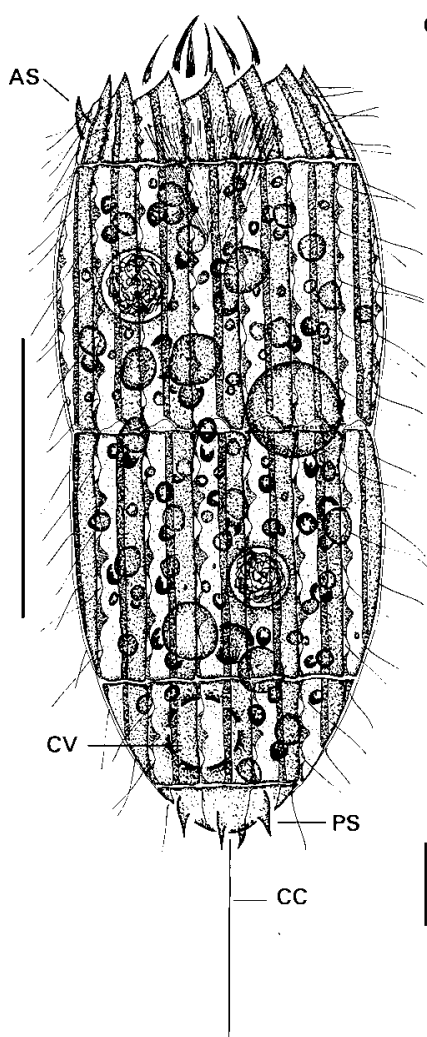

(a)

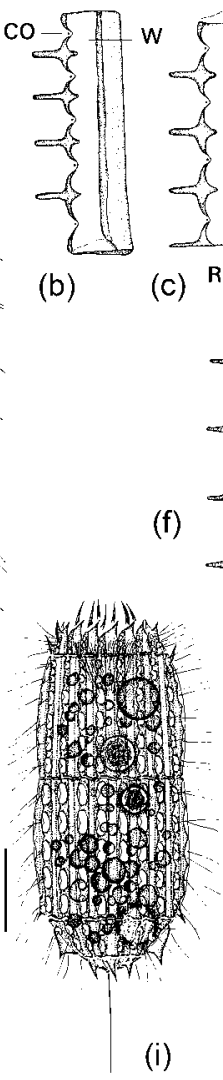

(i)

${ }^{\mathrm{R}}$

(f)
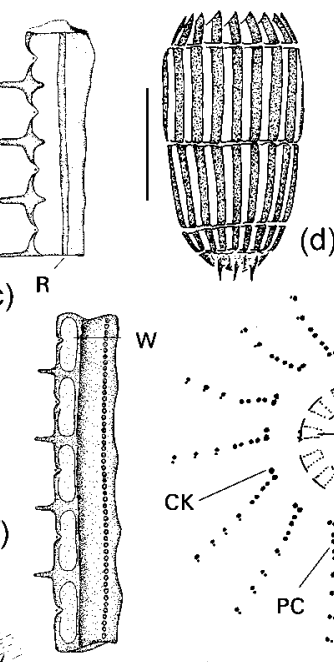

(e)
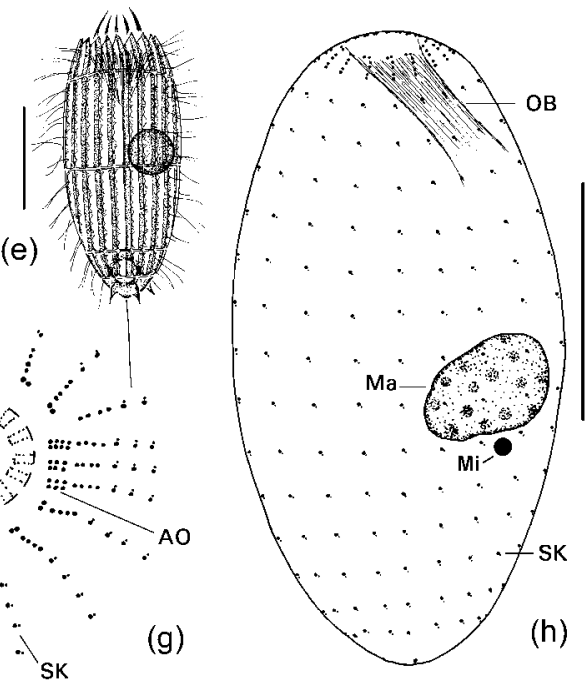

(h)

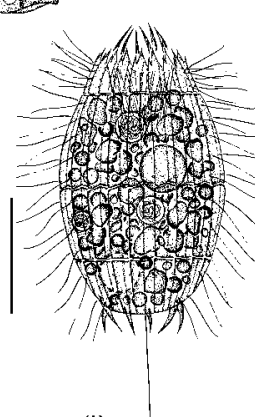

(j)

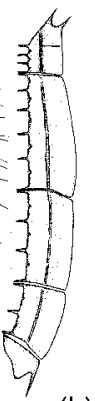

(k)

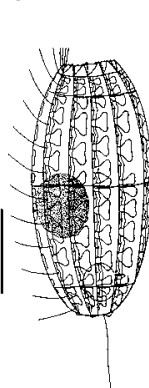

(l)

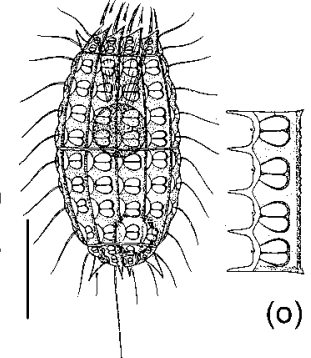

(n)

Fig. 1. Morphology and infraciliature of Nolandia sinica spec. nov. (a-e, g, h), Nolandia orientalis Chen et al., 2010 (f, i), Pinacocoleps similis (Kahl, 1933) Chen et al., 2010 (j, k), Nolandia nolandi (Kahl, 1930) Small \& Lynn, 1985 (I, m), Coleps hirtus hirtus (Müller, 1786) Nitzsch, 1827 (n, o). (a) Lateral view of a typical individual. (b) Detail of anterior main plate. (c) Detail of posterior main plate. $(d, e)$ Showing variations in body shape. (f) Posterior main plate of $N$. orientalis. (g) Ciliary pattern at apical end of body. (h) Lateral view of a protargol-impregnated specimen, showing infraciliature and nuclear apparatus. (i) Lateral view of $N$. orientalis (from Chen et al., 2010). (j) Lateral view of Pinacocoleps similis (from Chen et al., 2010). (k) Detail of armour plates of Pinacocoleps similis. (I) Lateral view of N. nolandi (from Wilbert \& Schmall, 1976). (m) Detail of main plate of N. nolandi. (n) C. hirtus hirtus (from Foissner, 1984). (o) Detail of main plate of C. hirtus hirtus. AO, adoral organelle; AS, anterior spine; CC, caudal cilium; CK, circumoral kinety; CO, ciliary outlet; CV, contractile vacuole; IB, inner oral basket; Ma, macronucleus; Mi, micronucleus; OB, outer oral basket; PC, perioral ciliary; PS, posterior spine; R, ridge; SK, somatic kinety; W, window. Bars, $20 \mu \mathrm{m}$. 

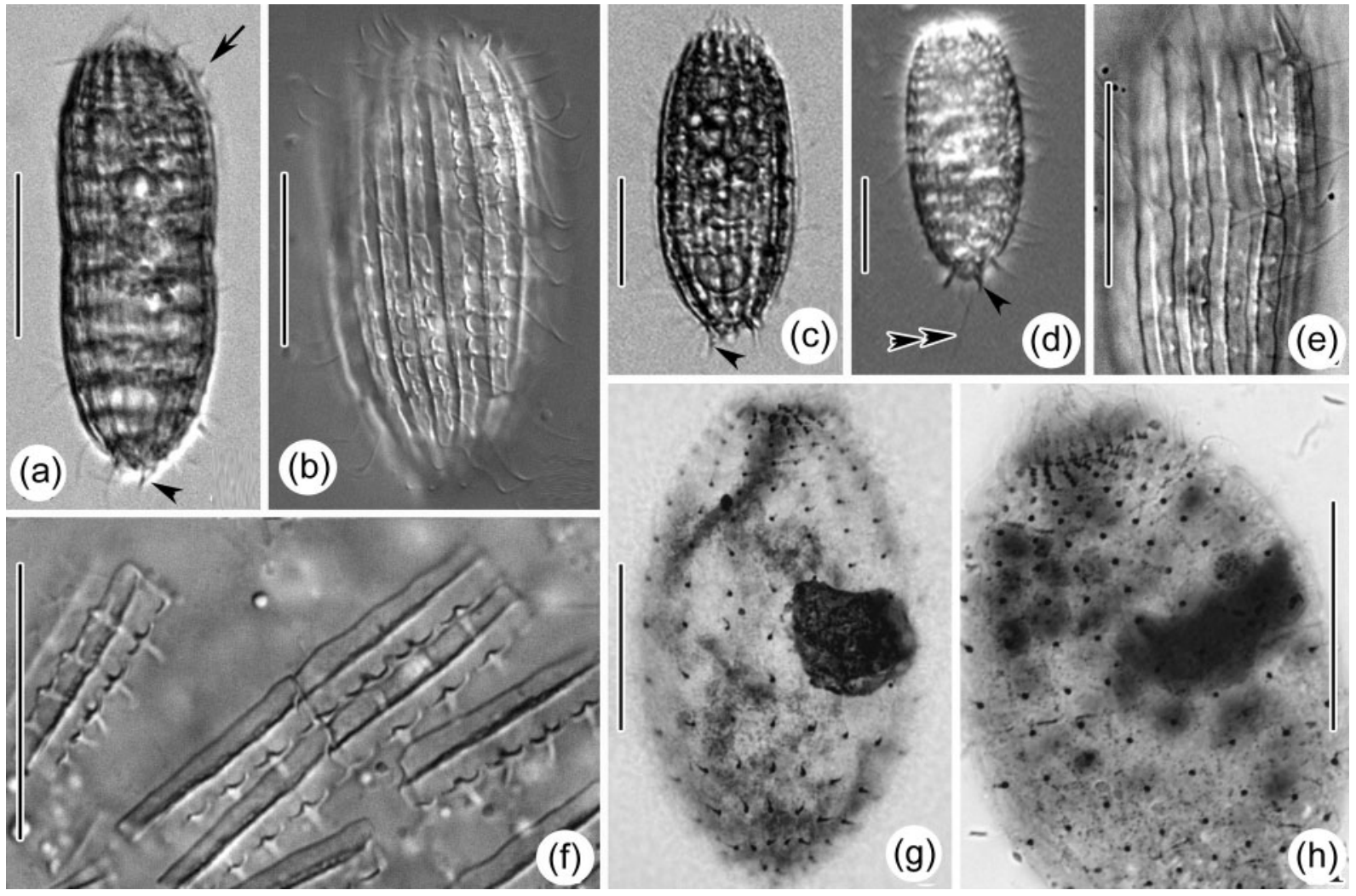

Fig. 2. Nolandia sinica spec. nov. from life $(a-f)$, after silver carbonate impregnation $(g, h)$. $(a, c, d)$ Lateral views, showing the body shape, posterior spines (arrowheads), anterior spine (arrow) and caudal cilium (double arrowheads in d). (b, e) Lateral views to show the surface detail; note the large, interconnected windows. (f) Detail of a squashed specimen showing the individual plates. $(\mathrm{g}, \mathrm{h})$ Lateral views, showing the ciliary pattern. Bars, $20 \mu \mathrm{m}$.

Table 1. Morphometric characteristics of Nolandia sinica spec. nov., Apocoleps caoi spec. nov. and Tiarina fusa

Data are based on protargol-impregnated specimens. $n$, Number.

\begin{tabular}{|lllrrrr|}
\hline Character & Species & Min & Max & Mean & SD & $\boldsymbol{n}$ \\
\hline \multirow{2}{*}{ Body length $(\mu \mathrm{m})$} & N. sinica & 54 & 60 & 57.6 & \pm 2.0 & 25 \\
& A. caoi & 96 & 120 & 106.7 & \pm 8.1 & 15 \\
& T. fusa & 56 & 75 & 64.0 & \pm 5.0 & 25 \\
Body width $(\mu \mathrm{m})$ & N. sinica & 28 & 36 & 32.2 & \pm 2.7 & 25 \\
& A. caoi & 34 & 57 & 49.2 & \pm 5.9 & 15 \\
& T. fusa & 18 & 25 & 20.8 & \pm 1.8 & 25 \\
Somatic kineties $(n)$ & N. sinica & 15 & 17 & 16.0 & \pm 0.7 & 25 \\
& A. caoi & 19 & 24 & 21.1 & \pm 1.5 & 15 \\
Kinetosomes in & T. fusa & 15 & 16 & 15.7 & \pm 0.4 & 25 \\
each kinety $(n)$ & N. sinica & 15 & 15 & 15.0 & \pm 0 & 25 \\
& & & & & & \\
& A. caoi & 22 & 24 & 23.0 & \pm 0.8 & 15 \\
Macronucleus & T. fusa & 32 & 41 & 34.5 & \pm 2.3 & 25 \\
length $(\mu \mathrm{m})$ & N. sinica & 12 & 20 & 13.3 & \pm 1.7 & 25 \\
& & & & & & \\
& A. caoi & 11 & 16 & 14.0 & \pm 1.4 & 15 \\
& T. fusa & 12 & 20 & 14.6 & \pm 2.1 & 25 \\
& & & & & & \\
& & & & & &
\end{tabular}

Type material. A protargol slide containing the holotype specimen encircled on the coverslip is deposited in the Natural History Museum, London, UK, with registration number NHMUK 2010.2.2.1. One paratype slide has been deposited in the collection of the Laboratory of Protozoology, OUC, China, with registration number WYG-2007050702.

Etymology. The specific epithet sinica refers to the fact that this organism was first isolated from China.

Description. Shape of body somewhat variable but generally cylindrical or barrel-shaped; usually slightly narrowed at mid-body where the main plates of armour abut; laterally flattened in a ratio of $5: 4$. Anterior end flat, truncated; posterior end of body tapering moderately to rounded tip (Figs 1a, d, e and 2a). Endoplasm colourless to brownish and opaque; typically packed with granules $2-5 \mu \mathrm{m}$ in diameter and food vacuoles approximately $10 \mu \mathrm{m}$ in diameter (Figs 1a and 2a). Macronucleus spherical, measuring approximately $8-10 \mu \mathrm{m}$ in diameter; micronucleus approximately $2 \mu \mathrm{m}$ in diameter, adherent to macronucleus (Fig. 1h). Contractile vacuole caudal (Fig. 1a, e). Armour composed of Nolandiatype plates arranged in six tiers, (1) circumoral, (2) anterior secondary, (3) anterior main, (4) posterior main, (5) 


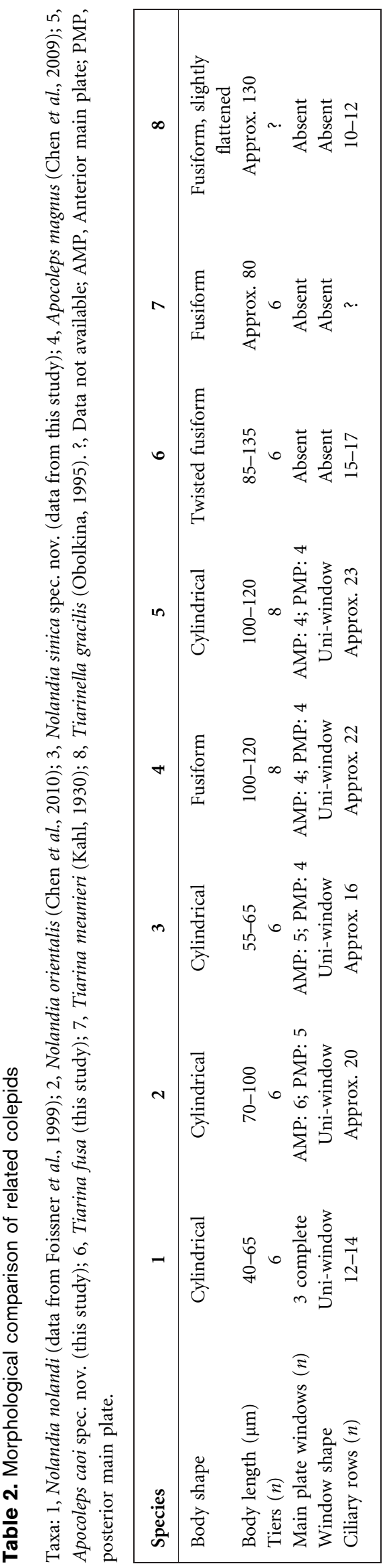

posterior secondary and (6) caudal, each of which comprises approximately 16 rectangular plates. Circumoral tier poorly visible in vivo. Anterior secondary plates with sharply pointed anterior ends; some with inconspicuous anterior spines (Figs 1a and 2a). Anterior main plates usually with five windows (Fig. 1a, b), posterior main plates with four (Fig. 1a, c), and posterior secondary plates with two. Caudal tier visible only in oblique or posterior polar views, with posterior spines up to $5 \mu \mathrm{m}$ long (Figs 1a, d, e and 2a, c, d). Main features of plates include reniform uni-windows near right margin, large interconnected windows, and inconspicuous borders between adjacent windows that combine to form a mean of 16 longitudinal canals across surface of cell (Figs 1a-c and 2b, e, f). Teeth on right margin of each plate approximately $5 \mu \mathrm{m}$ long, alternating with windows. Longitudinal ridge of plates smooth, thickened and lying slightly nearer left margin than right; left margin very slightly serrated and never wing-like.

Oral opening in centre of anterior pole. Circumoral kinety consisting of ring of dikinetids located next to anterior ends of somatic kineties, interrupted by adoral organelles (Fig. $1 \mathrm{~g})$. Adoral organelles 1 and 2 consisting of three dikinetids, organelle 3 consisting of four dikinetids. Oral basket approximately $15 \mu \mathrm{m}$ in length, located in centre of cytostome.

Somatic cilia $8-10 \mu \mathrm{m}$ long, regularly arranged, forming a mean of 15 transverse circumferential rows and 16 longitudinal rows (Figs $1 \mathrm{~g}$, $\mathrm{h}$ and $2 \mathrm{~g}, \mathrm{~h}$ ). Two dikinetids at anterior end of each ciliary row collectively form perioral ciliature. One caudal cilium approximately $20 \mu \mathrm{m}$ long (Figs 1a and $2 \mathrm{~d})$.

\section{Remarks and comparisons}

The genus Nolandia was established by Small \& Lynn (1985) although neither a diagnosis nor a detailed description was provided. The genus Nolandia is characterized by the structure of its armour plates, these being arranged in six tiers. Two species have previously been described: $N$. nolandi (Kahl, 1930) Small \& Lynn, 1985 and Nolandia orientalis Chen et al., 2010.

$N$. sinica differs from $N$. nolandi in the following plate features: (1) teeth of right plate margin alternately arranged with windows (vs at same level as windows); (2) teeth very long and finger-shaped (vs teeth short and thorn-like) (Fig. 1b, c, 1 and Table 2; Wilbert \& Schmall 1976). The divergence of these two forms is also supported by SSU rRNA gene sequence data which show a difference of $65 \mathrm{nt}$ (Table 3).

$N$. sinica can likewise be distinguished from $N$. orientalis by the structure of the armour plates: (1) windows large, border between adjacent windows inconspicuous (vs windows with wide and conspicuous border between adjacent windows); (2) ridge conspicuous and thickened, slightly nearer the left margin (vs ridge inconspicuous and slightly nearer the right margin); (3) absence of granules near left plate margin (vs 
Table 3. SSU rRNA gene sequence dissimilarities (lower triangle) and number of different sites (upper triangle) among eight colepids Species described in the present study are marked in bold.

\begin{tabular}{|c|c|c|c|c|c|c|c|c|}
\hline \multirow[t]{2}{*}{ Species } & \multicolumn{8}{|c|}{ SSU rRNA gene sequence dissimilarities/number of different sites with: } \\
\hline & 1 & 2 & 3 & 4 & 5 & 6 & 7 & 8 \\
\hline 2 Nolandia sinica & 2.79 & * & 65 & 37 & 33 & 102 & 101 & 110 \\
\hline 3 Nolandia nolandi & 4.16 & 3.88 & * & 71 & 67 & 70 & 74 & 76 \\
\hline 4 Apocoleps magnus & 3.15 & 2.20 & 4.24 & * & 4 & 106 & 111 & 106 \\
\hline 7 Coleps spetai & 6.69 & 6.03 & 4.34 & 6.62 & 6.38 & 1.17 & * & 107 \\
\hline 8 Levicoleps biwae & 6.12 & 6.54 & 4.46 & 6.30 & 6.06 & 6.16 & 6.28 & $\star$ \\
\hline
\end{tabular}

granules present) (Fig. 1b, c, f, i and Table 2; Chen et al., 2010).

In terms of body shape and size, position of contractile vacuole, and the caudal cilium, two other colepid species should be compared with $N$. sinica, namely Pinacocoleps similis (Kahl, 1933) Chen et al., 2009 and Coleps hirtus (Müller, 1786) Nitzsch, 1827. Both can be easily distinguished from $N$. sinica by the plate windows, these being absent in Pinacocoleps similis and pretzel-shaped biwindows in $C$. hirtus, whereas $N$. sinica has reniform uniwindows (Fig. 1a, b, j, k, n, o and Table 2; Chen et al., 2010; Foissner et al., 1999).

\section{Apocoleps Chen et al., 2009}

\section{Apocoleps caoi spec. nov. (Figs 3 and 4; Tables 1-3)}

Diagnosis. Large Apocoleps with elongated body, about $100-120 \times 35-60 \mu \mathrm{m}$ in vivo; anterior tertiary, anterior secondary and anterior main tier plates all with four uniwindows, posterior main and secondary tier plates each with three or four uni-windows, posterior tertiary tier plate with two uni-windows; left plate margin slightly serrated; a mean of about 23 transverse and 21 longitudinal ciliary rows; one terminal contractile vacuole; marine habitat.

Type locality. Sandy beach near Jiaozhou Bay, Qingdao, China $\left(36^{\circ} 06^{\prime} \mathrm{N} 120^{\circ} 29^{\prime} \mathrm{E}\right)$.

Type material. A protargol slide containing the holotype specimen encircled on the coverslip is deposited in the Natural History Museum, London, UK, with registration number NHMUK 2010.2.2.2. One paratype slide has been deposited in the collection of the Laboratory of Protozoology, OUC, China, with registration number WYG2007060702.

Etymology. This species is named in honour of Professor Wenxuan Cao, Institute of Hydrobiology, Wuhan, Chinese
Academy of Sciences, in recognition of his contributions to zoology.

Description. Body $100-120 \times 35-60 \mu \mathrm{m}$ in vivo, elongated and sometimes slightly curved, body widest in anterior quarter, gradually narrowing posteriorly (Figs 3a, c and 4a, b). Cytoplasm slightly greyish, often with numerous oily globules, $4-5 \mu \mathrm{m}$ in diameter, that render the main part of the body opaque, and several large, approximately $10 \mu \mathrm{m}$ diameter, brownish food vacuoles. One spherical macronucleus, approximately $12-15 \mu \mathrm{m}$ in diameter, located in mid-body; one micronucleus, approximately $2 \mu \mathrm{m}$ across, attached to macronucleus (Figs $3 \mathrm{~d}$ and $4 \mathrm{e}$ ). One contractile vacuole usually terminally positioned (Figs $3 a, c$ and $4 b$ ).

Armour composed of Nolandia-type plates arranged in eight tiers, (1) circumoral, (2) anterior tertiary, (3) anterior secondary, (4) anterior main, (5) posterior main, (6) posterior secondary, (7) posterior tertiary and (8) caudal, each tier consisting of a mean of 21 rectangular plates. Circumoral tiers hardly recognizable in vivo. Anterior tertiary plates with acutely pointed anterior ends, some with anterior spines (Figs $3 \mathrm{a}$ and $4 \mathrm{~b}, \mathrm{~g}$ ). Anterior secondary and main plates each with four windows, posterior main and secondary plates each with three or four windows, posterior tertiary plates each with two windows. Caudal tier with several long, conspicuous posterior spines (Figs 3a, c and 4a, b). Detailed structure of armour plates as shown in Figs 3(g) and $4(\mathrm{f}-\mathrm{h})$. Main features are as follows: plate approximately $20 \mu \mathrm{m}$ in length, with teeth about $2 \mu \mathrm{m}$ long; ridge at left plate margin, slightly serrated; conspicuous bridge connecting teeth and plate ridge; reniform uni-windows near right margin.

Oral opening in centre of anterior pole. Circumoral kinety consisting of ring of dikinetids located next to anterior ends of somatic kineties, interrupted by adoral organelles. Adoral organelles formed by three short, obliquely arranged rows (Figs $3 \mathrm{f}$ and $4 \mathrm{i}$ ). Organelles 1 and 2 each consisting of four dikinetids, organelle 3 of three dikinetids. 

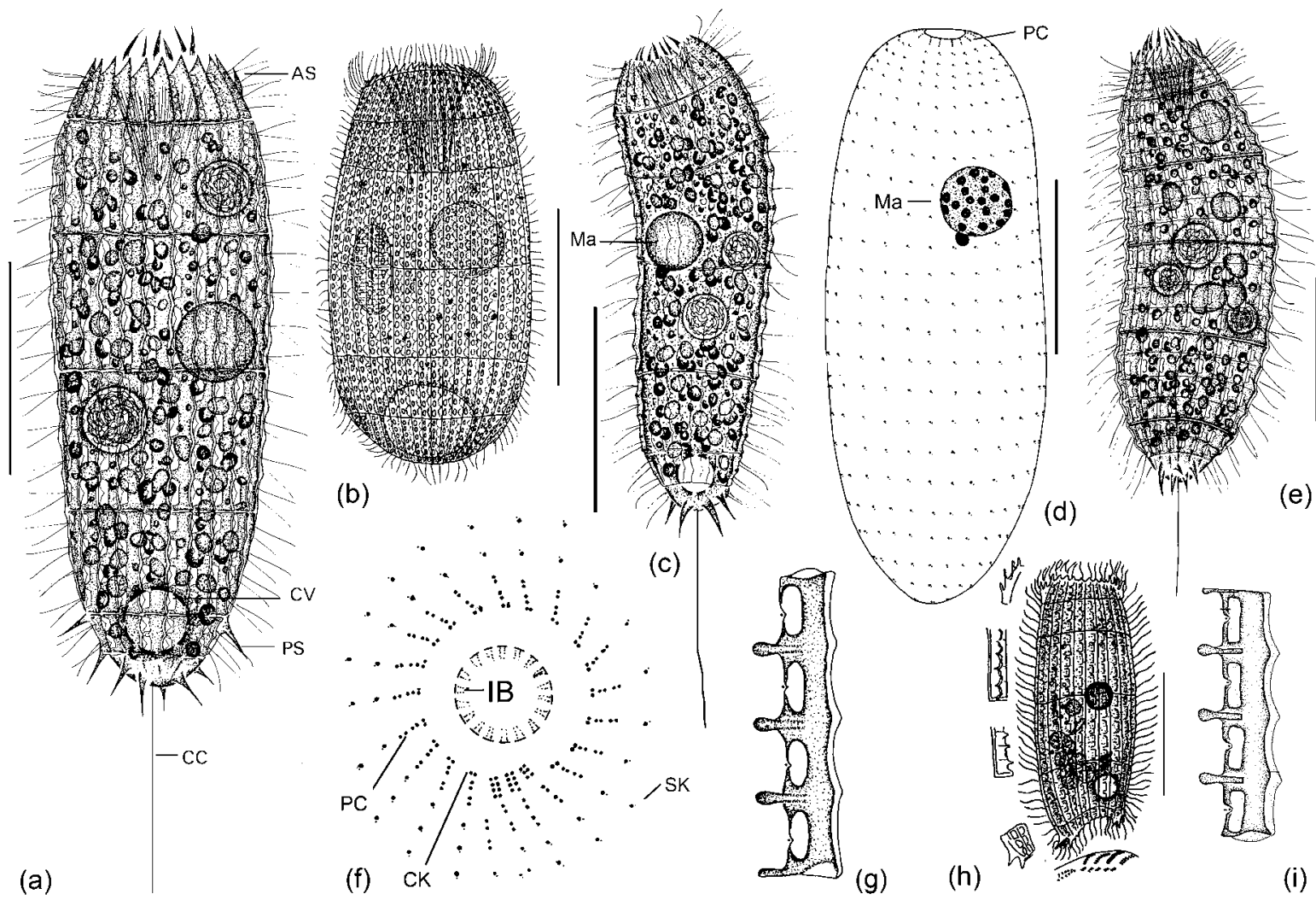

(e)

(i)

Fig. 3. Morphology and infraciliature of Apocoleps caoi spec. nov. (a, c, d, f, g) and three related morphotypes. (a) Lateral view of a typical individual. (b) Planicoleps psammophilus Dragesco \& Dragesco-Kernéis, 1991 (from Dragesco \& DragescoKernéis, 1991). (c) Lateral view of a slightly curved individual of $A$. caoi. (d) Lateral view, showing the ciliary pattern of $A$. caoi. (e) Apocoleps magnus Chen et al., 2009 (from Chen et al., 2009). (f) Ciliary pattern of anterior end of $A$. caoi. (g) Detail of armour plate of $A$. caoi. (h) Kotinia heterolobata (Obolkina, 1995) Obolkina in Aescht, 2001 (from Obolkina, 1995). (i) Detail of armour plate of $A$. magnus (from Chen et al., 2009). AS, anterior spine; CC, caudal cilium; CK, circumoral kinety; CV, contractile vacuole; IB, inner oral basket; Ma, macronucleus; PC, perioral ciliary; PS, posterior spine; SK, somatic kinety. Bars, $30 \mu \mathrm{m}$.

Oral basket in centre of cytostome, conspicuous in protargol-stained specimens (Figs $3 \mathrm{f}$ and $4 \mathrm{e}, \mathrm{i}$ ).

Somatic cilia regularly arranged, forming a mean of 23 circumferential rows and 21 longitudinal rows. Two dikinetids at anterior end of each ciliary row collectively form perioral ciliature. One caudal cilium approximately $30 \mu \mathrm{m}$ long (Fig. 3a, d).

\section{Remarks and comparisons}

The genus Apocoleps was established as a monotypic genus with $A$. magnus as the type species by original designation (Chen et al., 2009). It is characterized by the possession of Nolandia-type plates arranged in eight tiers.

A. caoi may be separated from A. magnus, its only congener, by the following features: (1) body widest at anterior end, posterior portion gradually narrowed (vs body widest in midregion, both ends conspicuously narrowed) (Fig. 3a, e); (2) 1012 long, sharp posterior spines (vs approx. 6-8 short and thorn-like posterior spines) (Chen et al., 2009). The separation of these two species is also weakly supported by molecular data, their SSU rRNA gene sequences differing by 4 nt (Table 3).

Considering the large size and high number of armour tiers, two other species should also be compared with A. caoi, namely Kotinia heterolobata (Obolkina, 1995) Obolkina in Aescht, 2001 and Planicoleps psammophilus Dragesco \& Dragesco-Kernéis, 1991. A. caoi differs from $K$. heterolobata (Obolkina, 1995) in the body shape (posterior end moderately tapering vs posterior end truncated), body size $(100-120 \times 35-60 \mu \mathrm{m}$ vs $120-200 \times 50-63 \mu \mathrm{m})$, the number of adoral organelles (three vs five), and habitat (marine vs freshwater) (Fig. 3h; Table 2; Obolkina, 1995). A. caoi can be separated from Planicoleps psammophilus by the following characters: body shape (body widest in anterior region, circular in transverse section vs body widest in posterior region and conspicuously flattened), the number and shape of main plate windows (four reniform uni-windows vs approx. 10 oval uni-windows), the shape of the left plate margin (slightly serrated vs smooth and 

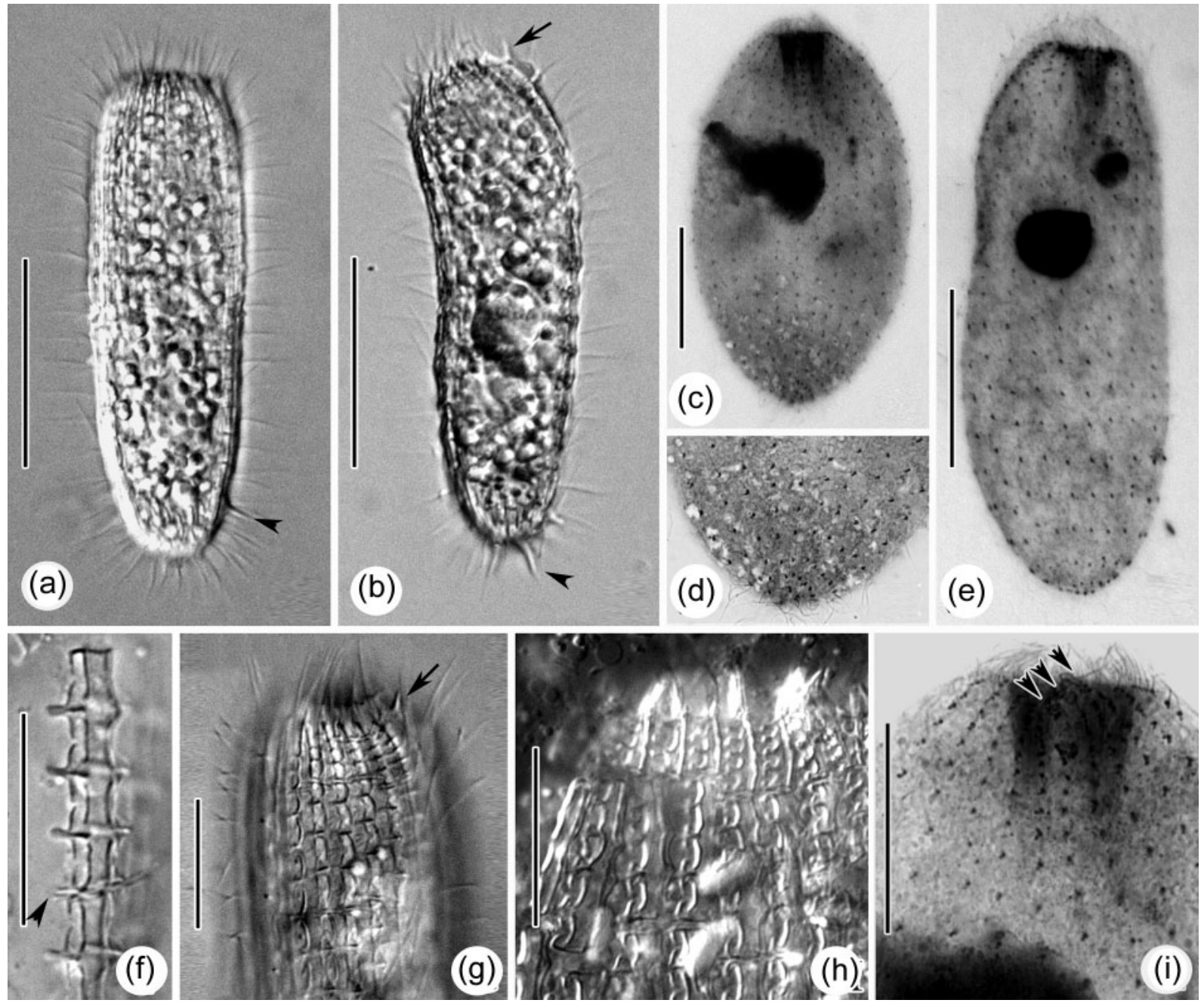

Fig. 4. Apocoleps caoi spec. nov. from life $(\mathrm{a}, \mathrm{b}, \mathrm{f}-\mathrm{h})$, after protargol impregnation (e, i) and silver carbonate impregnation (c, d). (a) Lateral view of a typical specimen, showing the body shape and posterior spines (arrowhead). (b) Lateral view of an unusual specimen, showing the curved body and the anterior spine (arrow) and posterior (arrowhead) spines. (c, e) Lateral views showing the ciliary pattern. (d) Detail of posterior region, showing the ciliary pattern. (f) Detail of main armour plate; arrowhead indicates the gap between two plates. (g) Detail of anterior region, showing the anterior tertiary tier plates and anterior spine (arrow). (h) Surface detail showing armour plates. (i) Anterior end of cell, showing the ciliary pattern and adoral organelles (arrowheads). Bars, $30 \mu \mathrm{m}(\mathrm{a}-\mathrm{e})$ and $15 \mu \mathrm{m}(\mathrm{f}-\mathrm{i})$.

straight), and the number of perioral kinetosomes (two pairs vs approx. seven or eight pairs) (Fig. 3b; Table 2; Dragesco \& Dragesco-Kernéis, 1991).

\section{Tiarina Bergh, 1881}

\section{Tiarina fusa (Claparède \& Lachmann, 1858) Bergh, 1881 (Fig. 5; Tables 1-3)}

Synonym: Coleps fusus Claparède \& Lachmann, 1858

Some new data have been obtained from the population studied here; thus we present an updated description and an improved diagnosis.
Improved diagnosis. About $60-135 \times 20-30 \mu \mathrm{m}$ in vivo, body spindle-shaped; a mean of 16 longitudinal ciliary rows, each with approximately 35 kinetosomes; armour plates rectangular, with conspicuous longitudinal ridge and triangular teeth; one macronucleus and one micronucleus; marine habitat.

Slide deposition. Voucher slides of protargol-stained cells have been deposited in the collections of the Natural History Museum, London, UK (registration number NHMUK 2010.2.2.3) and the Laboratory of Protozoology, OUC, China (registration number LWW-20071013).

Description. Body usually about $80 \times 20 \mu \mathrm{m}$ in vivo, ratio of length to width about $4: 1$, circular in cross-section. 


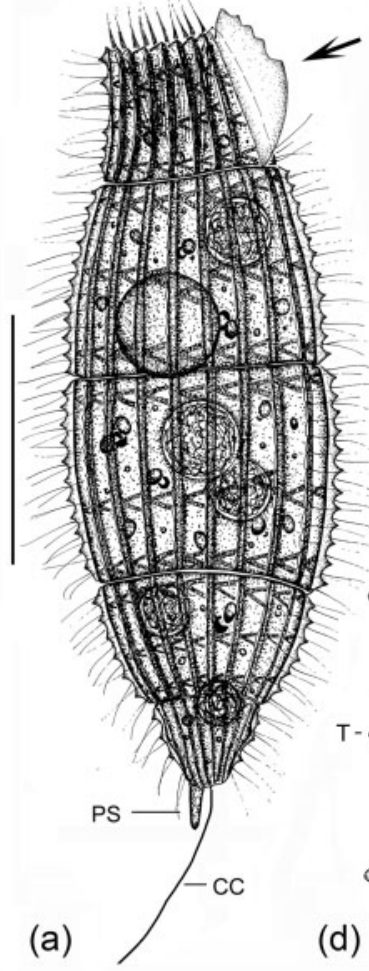

(d)

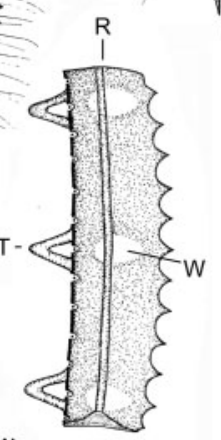

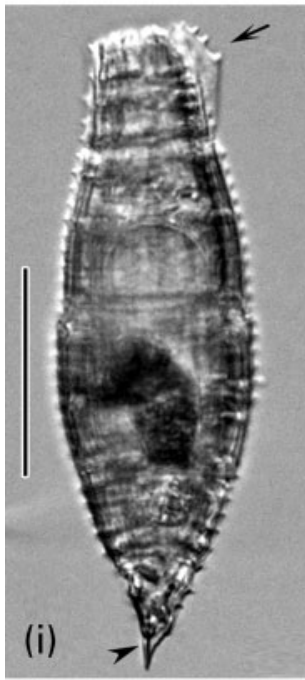

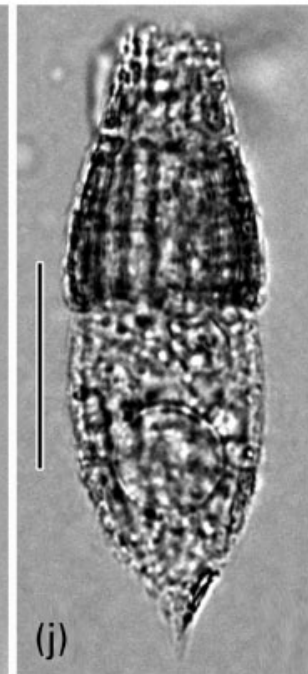

(e)

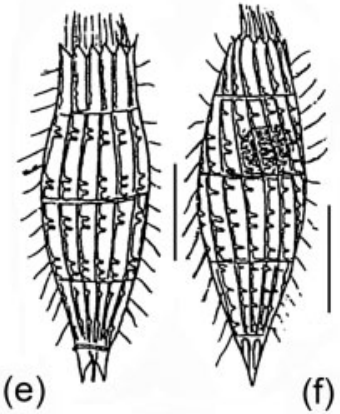

(f)
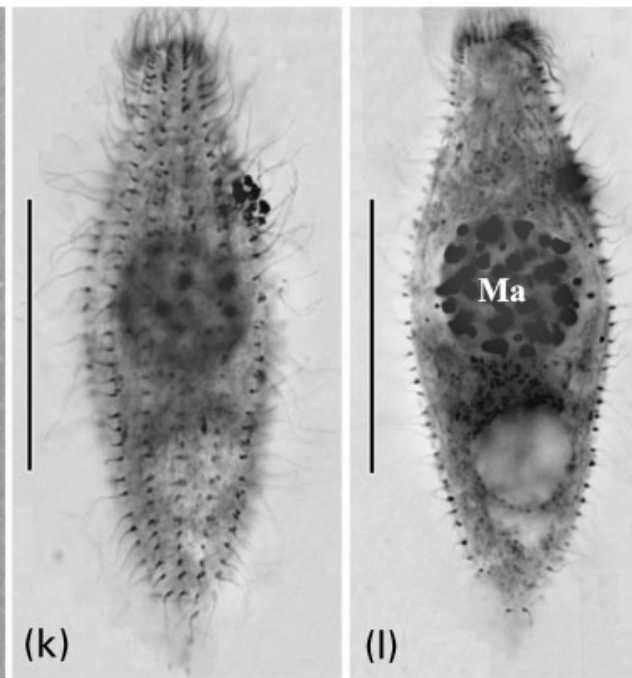

(g)

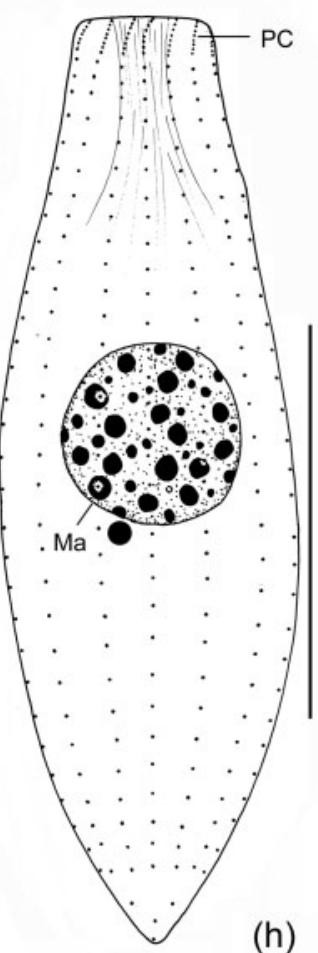

(h)
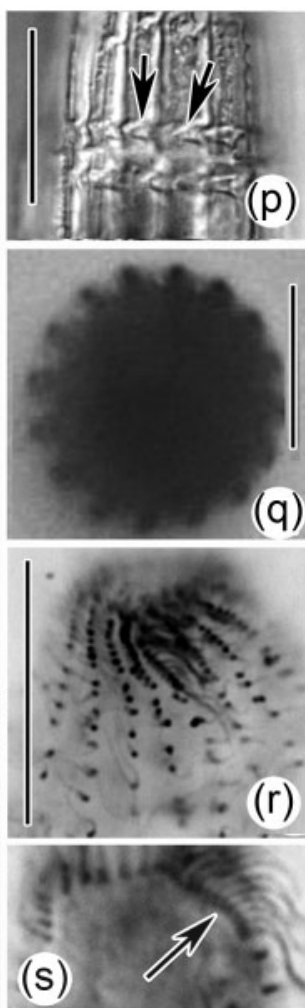

Fig. 5. Morphology and infraciliature of Tiarina fusa (Claparède \& Lachmann, 1858) Bergh, 1881. (a) Lateral view of a typical specimen, showing the body shape and wing-like structure (arrow). (b) Transverse section, showing the arrangement of armour plates; arrows indicate the cilia. (c) Ciliary pattern of anterior end. (d) Detail of the main armour plate. (e, $f$ ) Lateral views of two specimens (from Kahl, 1930). (g) Lateral view, showing the ciliary pattern and three adoral organelles (from Small \& Lynn, 1985). (h) Lateral view, showing the ciliary pattern and nuclear apparatus. (i) Lateral view of a typical specimen, showing the 
body shape, pointed posterior end (arrowhead) and wing-like structure (arrow). (j) Lateral view of cell during binary fission; the posterior body half is brighter because the new armour plates are colourless and transparent. $(k, I)$ Lateral views to show the ciliary pattern and nuclear apparatus. $(m-o)$ Detail of plates, showing the ridge (arrows) and serrated left margin (arrowheads). ( $p$ ) Detail of armour plates; arrows mark the conspicuous teeth. (q) Transverse view, showing the circular cross-section. ( $r$, $s$ ) Detail of anterior end, showing the ciliary pattern and adoral organelle (arrow). AO, adoral organelle; CC, caudal cilium; Ma, macronucleus; PC, perioral ciliary; PS, posterior spine; R, ridge; SK, somatic kinety; T, tooth. Bars, $30 \mu \mathrm{m}(\mathrm{a}-\mathrm{I})$ and $15 \mu \mathrm{m}(\mathrm{m}-\mathrm{s})$.

Body spindle-like, anterior end truncated, posterior region gradually tapering to a sharp point (Fig. 5a, b, i, j). Endoplasm colourless to brownish and opaque, packed with granules $2-3 \mu \mathrm{m}$ in diameter and food vacuoles 5 $8 \mu \mathrm{m}$ across (Fig. 5a). Macronucleus spherical, approximately $10 \mu \mathrm{m}$ in diameter, single spherical micronucleus near macronucleus (Fig. 5a, h, l).

Armour composed of Tiarina-type plates arranged in six tiers, (1) circumoral, (2) anterior secondary, (3) anterior main, (4) posterior main, (5) posterior secondary and (6) caudal, each tier comprising a mean of 16 rectangular plates. Circumoral tier plates difficult to observe in vivo. Anterior secondary plates rectangular, one of which possesses a conspicuous wing-like structure (Fig. 5a, i). Anterior main, posterior main and posterior secondary tier plates each with three sturdy teeth. Caudal tier plates triangular, sharply pointed posteriorly. Usually with a single conspicuous posterior spine. Fine structure of armour plates as shown in Fig. 5(d, m-o). Main features as follows: windows absent but with three thin, transparent rounded areas at levels of teeth of right plate margin; teeth sturdy and triangular; longitudinal ridge thickened and smooth, slightly nearer right margin; left plate margin distinctly crenellated and wing-like.

Oral opening in centre of anterior pole. Only one adoral organelle observed, formed by two densely arranged kinety rows, each comprising about 12-15 kinetosomes (Fig. 5c, r, s). Oral basket approximately $16 \mu \mathrm{m}$ long.

Somatic cilia 5-6 $\mu \mathrm{m}$ long and regularly arranged, forming about 16 longitudinal rows, each comprising about 35 kinetosomes. Anterior ends of ciliary rows each with 7 or 8 densely packed kinetosomes that collectively form the perioral ciliature (Fig. 5h, s). One caudal cilium 15-20 $\mu \mathrm{m}$ long (Fig. 5a).

\section{Remarks and comparisons}

Tiarina fusa was first reported by Claparède \& Lachmann (1858) under the name Coleps fusus, but Bergh (1881) subsequently transferred it to the genus Tiarina. The divergence of Tiarina fusa from the genus Coleps is supported by the SSU rRNA gene sequence data, which shows that the former differs in 109 and $114 \mathrm{nt}$ from $C$. hirtus hirtus and C. spetai, respectively (Table 3 ).

Although Tiarina fusa has previously been investigated several times based on living and fixed specimens, the detailed structure of the armour plates and adoral organelles has never been reported. Small \& Lynn (1985), for example, provided only a brief description and a schematic figure showing three oblique adoral organelles. By contrast, the present study has revealed only one long, oblique adoral organelle in the China population.

Morphologically, Tiarina fusa is very similar to Tiarina meunieri Kahl, 1930 in terms of its body shape and size and its marine habitat. However, the former can be distinguished from the latter by the wing-like structure at the anterior end of the body (absent in Tiarina meunieri) and the presence of a single spherical macronucleus (vs generally moniliform with 5-8 macronuclear segments in Tiarina meunieri) (Table 2; Kahl, 1930).

With reference to the body shape and size, Tiarina fusa should also be compared with Tiarinella gracilis Obolkina, 1995, the former being separated from the latter as follows: (1) body never flattened vs body slightly flattened; (2) anterior end with wing-like structure vs anterior without a wing-like structure; (3) single posterior spine vs three or four posterior spines; (4) approximately 16 longitudinal somatic kineties vs 10-12 longitudinal somatic kineties; (5) single long, oblique adoral organelle vs three short adoral organelles (Table 2; Obolkina, 1995).

\section{ACKNOWLEDGEMENTS}

This work was supported by the Natural Science Foundation of China (project no. 30870264, 41006086) and the King Saud University Deanship of Scientific Research (research group project no. RGPVPP-083). We thank Dr Yangang Wang, Laboratory of Protozoology, OUC, for his help in collecting samples. We greatly appreciate the comments of the three anonymous reviewers who helped to significantly improve our manuscript.

\section{REFERENCES}

Bergh, R. S. (1881). Bidrag til Cilioflagellaternes Naturhistorie. Videnskabel Meddel Fr D Naturhist Forening Kjøbenhavn 3, 60-76.

Chen, X., Warren, A. \& Song, W. (2009). Taxonomic studies on a new marine ciliate, Apocoleps magnus gen. nov., spec. nov. (Ciliophora, Colepidae), isolated from Qingdao, China. J Ocean Univ China 8, 317321.

Chen, X., Wang, Y., Long, H., Al-Rasheid, K. A., Warren, A. \& Song, W. (2010). Morphological studies on two marine colepid ciliates from Qingdao, China, Nolandia orientalis spec. nov. and Pinacocoleps similis (Kahl, 1933) comb. nov. (Ciliophora, Colepidae). Eur J Protistol 46, 254-262.

Claparède, É. \& Lachmann, J. (1858). Études sur les infusoires et les rhizopodes. Mém Inst Natn Génev 6, 261-482. 
Corliss, J. O. (1979). The Ciliated Protozoa. Characterization, Classification and Guide to the Literature, 2nd edn. Oxford: Pergamon Press.

Dragesco, J. \& Dragesco-Kernéis, A. (1991). Free-living ciliates from the coastal area of Lake Tanganyika (Africa). Eur J Protistol 26, 216-235.

Foissner, W. (1984). Infraciliatur, Silberliniensystem und Biometrie einiger neuer und wenig bekannter terrestrischer, limnischer und mariner Ciliaten (Protozoa: Ciliophora) aus den Klassen kinetofragminophora, Colpodea und Polyhymenophora. Stapfia 12, 1-165.

Foissner, W., Berger, H. \& Schaumburg, J. (1999). Identification and ecology of limnetic plankton ciliates. Informationsberichte des Bayer. Landesamtes für Wasserwirtschaft 3/99. Munich: Bartels und Wernitz Druck.

Foissner, W., Kusuoka, Y. \& Shimano, S. (2008). Morphology and gene sequence of Levicoleps biwae n. gen., n. sp. (Ciliophora, Prostomatida), a proposed endemic from the ancient Lake Biwa, Japan. J Eukaryot Microbiol 55, 185-200.

Huttenlauch, I. (1987). Ultrastructural aspects of the somatic and buccal infraciliature of Coleps ampacanthus Ehrenberg 1833. Protoplasma 136, 191-198.

Huttenlauch, I. \& Bardele, C. F. (1987). Light and electron microscopical observations on the stomatogenesis of the ciliate Coleps amphacanthus Ehrenberg, 1833. J Protozool 34, 183-192.

Kahl, A. (1930). Urtiere oder Protozoa I: Wimpertiere oder Ciliata (Infusoria) 1. Allgemeiner Teil und Prostomata. In Die Tierwelt Deutschlands und der angrenzenden Meeresteile, vol. 18, pp. 1-180. Edited by F. Dahl. Jena: Gustav Fischer (in German).

Kahl, A. (1933). Ciliata Libera et Ectocommensalia. In Die Tierwelt der Nord- und Ostsee, vol. 23, pp. 29-146. Edited by G. Grimpe \& E. Wagler. Leipzig: Akademische Verlagsgesellschaft (in German).

Ma, H., Choi, J. K. \& Song, W. (2003). An improved silver carbonate impregnation for marine ciliated protozoa. Acta Protozool 42, 161-164.
Müller, O. F. (1786). Animalcula Infusoria Fluviatilia et Marina, quae Detexit, Systematice Descripsit et ad Vivum Delineari Curavit. Hauniae: Typis N. Mölleri.

Noland, L. E. (1925). A review of the genus Coleps with descriptions of two new species. Trans Am Microsc Soc 44, 3-13.

Noland, L. E. (1937). Observations on marine ciliates of the Gulf Coast of Florida. Trans Am Microsc Soc 56, 160-171.

Obolkina, L. A. (1995). New species of the family Colepidae (Prostomatida, Ciliophora) from Lake Baikal. Zool Zh 74, 3-19 (in Russian).

Small, E. B. \& Lynn, D. H. (1985). Phylum Ciliophora Doflein, 1901. In An Illustrated Guide to the Protozoa, pp. 393-575. Edited by J. J. Lee, S. H. Hutner \& E. C. Bovee. Lawrence, KS: Society of Protozoologists.

Song, W. \& Wilbert, N. (1995). Benthische Ciliaten des Süßwassers. In Praktikum der Protozoologie, pp. 156-168. Edited by R. Röttger. New York: Gustav Fischer.

Wang, Y., Hu, X., Long, H., Al-Rasheid, K. A. S., Al-Farraj, S. A. \& Song, W. (2008a). Morphological studies indicate that Pleuronema grolierei nov. spec. and P. coronatum Kent, 1881 represent different sections of the genus Pleuronema (Ciliophora: Scuticociliatida). Eur J Protistol 44, 131-140.

Wang, Y., Miao, M., Zhang, Q., Gao, S., Song, W., Al-Rasheid, K. A. S., Warren, A. \& Ma, H. (2008b). Three marine interstitial scuticociliates, Schizocalyptra similis sp. n., S. sinica sp. n. and Hippocomos salinus Small and Lynn, 1985 (Ciliophora: Scuticociliatida), isolated from Chinese coastal waters. Acta Protozool 47, 377-387.

Wilbert, N. \& Schmall, G. (1976). Morphologie und Infraciliatur von Coleps nolandi Kahl, 1930. Protistologica 12, 193-197.

Yi, Z., Dunthorn, M., Song, W. \& Stoeck, T. (2010). Increasing taxon sampling using both unidentified environmental sequences and identified cultures improves phylogenetic inference in the Prorodontida (Ciliophora, Prostomatea). Mol Phylogenet Evol 57, 937-941. 